\title{
ANALISIS KRITERIA PENETAPAN NILAI BAGI HASIL PENDANAAN DENGAN MENGGUNAKAN TEKNIK ANP \\ (STUDI KASUS PADA BANK JATIM SYARIAH) ${ }^{1}$
}

\author{
Lolla Rizky Nanda Devita \\ Program Studi S1 Ekonomi Islam-Fakultas Ekonomi dan Bisnis-Universitas Airlangga \\ Email: lolla.rizky@yahoo.co.id \\ Dina Fitrisia Septiarini \\ Departemen Ekonomi Syariah-Fakultas Ekonomi dan Bisnis-Universitas Airlangga \\ Email: dina-f-s@feb.unair.ac.id
}

\begin{abstract}
:
The purpose of this study was to find out what is the main criteria in determining revenue sharing value of funding based on interdependence level of internal and external factors by using ANP techniques at Bank Jatim Syariah. The research method used is descriptive qualitative approach with study case method. Data collected by interviews, questionnaires, documentation and other literature. Analysis technique used is the technique of Analytic Network Process (ANP) with weighting questionnaires given to the informant. Weighting is done through comparison between the criteria, sub-criteria and sub-criteria traffic. Results from this study are the criteria of internal factors with sub criteria bank revenue of 0.17416 become a major criterion in the decision-making on determination of revenue sharing value of Funding in Bank Jatim Syariah. Results of the weighting of criteria and sub-criteria through the geometric mean of three informants of Bank Jatim Syariah.
\end{abstract}

Keywords: Islamic Banking, Revenue Sharing of Funding, Analysis Determination, Analytic Network Process (ANP)

\section{PENDAHULUAN}

Kondisi ekonomi suatu negara tercemin dari kondisi lembaga intermediasi salah satunya yaitu perbankan. Jika perbankan dapat menjalankan fungsinya dengan baik maka perekonomian suatu negara akan berjalan dengan baik pula. Terhitung sejak pertengahan bulan pada tahun 2015 lalu, terdapat sejumlah gejala masalah terkait kondisi ekonomi, antara lain melemahnya nilai tukar rupiah terhadap dollar AS, meningkatnya harga barang pokok yang berakibat inflasi, dan lain-lain. Hal ini berimbas pada para pengusaha yang mengandalkan harga barang pokok sebagai bahan produksi. Melemahnya kemampuan pengusaha dalam proses produksi akan menurunkan kemampuan bank untuk mendapatkan dana baik dari investasi maupun dari kredit. Bank merupakan lembaga intermediasi yang memiliki peran krusial dalam kegiatan ekonomi yang menyediakan beragam jasa kevangan. Bank adalah badan usaha yang menghimpun dana dari masyarakat dalam bentuk simpanan dan menyalurkannya kepada masyarakat dalam bentuk simpanan dan menyalurkannya kepada masyarakat

\footnotetext{
1) Jurnal ini merupakan bagian dari skripsi Lolla Rizky Nanda Devita, nim. 041211432115 , yang diuji pada tanggal 12 Februari 2016
} 
Devita, et al/Jurnal Ekonomi Syariah Teori dan Terapan Vol. 3 No. 8 Agustus 2016: 600-614; ANALISIS KRITERIA PENETAPAN NILAI BAGI HASIL PENDANAAN DENGAN MENGGUNAKAN TEKNIK ANP (STUDI KASUS PADA BANK JATIM SYARIAH)

dalam bentuk kredit dan atau bentukbentuk lainnya dalam rangka meningkatkan taraf hidup masyarakat (Undang-Undang Nomor 10 Tahun 1998).

Seiring dengan perkembangan ekonomi Islam yang bertujuan mencapai kesejahteraan ekonomi dan kebutuhan masyarakat melalui distribusi sumbersumber materiil yang merata dan melalui keadilan sosial (Chaudhry, 2012:32), terbentuk bank syariah sebagai lembaga yang melakukan kegiatannya sesuai dengan sistem ekonomi islam atau sesuai syariat islam yang mewujudkan falah bagi seluruh umat. Bank Islam lahir sebagai salah satu solusi alternatif terhadap persoalan pertentangan antara bunga bank dengan riba. Dengan demikian, kerinduan umat Islam Indonesia yang ingin melepaskan diri dari persoalan riba telah mendapat jawaban dengan lahirnya bank Islam. (Muhammad, 2004:2)

$$
\text { Pesatnya }
$$

perkembangan

perbankan syariah di Indonesia ditandai dengan berdirinya Bank Muamalat Indonesia tahun 1992. Bank Muamalat Indonesia merupakan satu-satunya bank syariah yang dapat bertahan secara stabil dalam menghadapi ketidakstabilan ekonomi. Bank Muamalat Indonesia dapat menjaga likuiditasnya dengan menggunakan sistem bagi hasil.

Setiap transaksi kelembagaan syari'ah harus dilandasi atas dasar sistem bagi hasil, seperti firman Allah SWT pada surat Al-Baqarah ayat 275:

$$
\begin{aligned}
& \text { الذيتـ يأكلون الربوا لا يقومون إلا كما يقوم } \\
& \text { الذى يتخبطه الشيطن من المس ذلك بأنهم } \\
& \text { قالوا إنما البيع مثل الربوا وأحل اله البيع وحرم } \\
& \text { الربوا فمن جاءور موعظة من ربهء فانتهى فله, ما } \\
& \text { سلف وأمرهد إلى الله ومــــ عاد فأولبك أصحنب } \\
& \text { النار هم فيها خنلدوب. }
\end{aligned}
$$

AlläÊna ya'kulëna'r-ribÉ lÉ

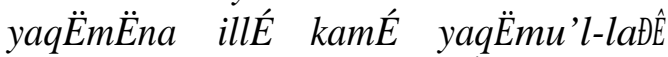
yatakha'b-baÏuhu 'sy-syaï̈Énu mina'lmassi ĐÉlika bi-annahum qÉlë innamÉ'l-bay'u mil̂lu'r-ribÉ wa'aÍlallaha'l-bay'a waÍarrama'rribÉ faman jÉ-ahu maw'il̈atun mi'rrabbihi fÉntahÉ falahu mÉ salafa waamruhu ilÉ'l-Lahi, waman 'Éda fa'ËlÉ'ika 'aÎIlabu'nnÉri hum fihÉ khÉlidën.

Artinya: "Orang-orang yang memakan riba tidak dapat berdiri melainkan seperti berdirinya orang yang kemasukan setan karena gila. Yang demikian itu karena mereka berkata bahwa jual beli itu sama dengan riba. Padahal Allah telah menghalalkan jual beli dan mengharamkan riba. Barang siapa mendapat peringatan dari Tuhannya, lalu dia berhenti, maka apa yang telah diperolehnya dahulu menjadi miliknya dan urusannya (terserah) kepada Allah. Barang siapa mengulangi, maka mereka itu penghuni neraka, mereka kekal di dalamnya." (Departemen Agama RI, 2007:47)

Menurut Tarsidin (2010), bagi hasil merupakan suatu bentuk skema pembiayaan alternatif, yang memiliki karakteristik yang sangat berbeda dibandingkan bunga. Muhammad (2004:19) mendefinisikan sistem bagi hasil sebagai sistem pembagian hasil kerjasama baik berupa keuntungan 
(profit) maupun pendapatan (revenue) berdasarkan nisbah yang telah disepakati di awal akad dari kerjasama minimal antara dua pihak atau lebih, satu pihak berperan sebagai penyandang dana dan pihak lainnya sebagai pekerja.

Berdasarkan penjelasan di atas maka sistem bagi hasil merupakan pembagian atas hasil usaha yang dibiayai dengan pembiayaan dan pemberian bagi hasil atas keuntungan bank syariah kepada pihak nasabah yang menabung dan mendepositkan uangnya sebagai bentuk pendanaan (funding) oleh bank. Bagi hasil dapat diaplikasikan baik pada pembiayaan langsung maupun pada pembiayaan melalui bank syariah (dalam bentuk pembiayaan mudharabah maupun musyarakah), begitu pula dengan produk pendanaan. Diantara produk yang menggunakan prinsip bagi hasil dalam penghimpunan dana adalah giro, tabungan dan deposito sebagai salah satu sumber pendanaan bagi operasional bank. Perbandingan bagi hasil salah satu produk pendanaan yaitu produk deposito antar dua bank syariah dapat dilihat pada tabel 1.1 berikut:

Tabel 1.

Perbandingan Bagi Hasil Deposito

\begin{tabular}{|l|c|c|c|c|}
\hline \multirow{2}{*}{} & \multicolumn{3}{|c|}{ Bagi Hasil Deposito } \\
\cline { 2 - 5 } & \multicolumn{2}{|c|}{$\begin{array}{c}\text { Bank Jatim } \\
\text { Syariah }\end{array}$} & \multicolumn{2}{c|}{ BNI Syariah } \\
\cline { 2 - 5 } & Nasabah & Bank & Nasabah & Bank \\
\hline $1 \mathrm{bln}$ & $52 \%$ & $48 \%$ & $49 \%$ & $51 \%$ \\
\hline $3 \mathrm{bln}$ & $54 \%$ & $46 \%$ & $51 \%$ & $49 \%$ \\
\hline $6 \mathrm{bln}$ & $56 \%$ & $44 \%$ & $53 \%$ & $47 \%$ \\
\hline $12 \mathrm{bln}$ & $58 \%$ & $42 \%$ & $55 \%$ & $45 \%$ \\
\hline
\end{tabular}

Sumber: Data diolah peneliti.
Tabel 1. menunjukkan adanya tingkat bagi hasil yang bersaing antar bank syariah. Dalam penetapannya, bagi hasil dapat dipengaruhi oleh beberapa kriteria. Kriteria merupakan ukuran yang menjadi dasar penilaian atau penetapan sesuatu. Kriteria tersebut dapat berupa faktor internal bank, kondisi perekonomian, dan sikap pemerintah.

Faktor internal bank salah satunya pendapatan merupakan hasil dari suatu perusahaan. Berdasarkan PSAK No. 23, pendapatan didefinisikan sebagai arus masuk bruto dari manfaat ekonomi yang timbul dari aktivitas normal entitas selama suatu periode jika arus masuk tersebut mengakibatkan kenaikan ekuitas, yang tidak berasal dari kontribusi penanam modal.

Dana yang telah diperoleh bank syariah akan dialokasikan untuk memperoleh pendapatan. Dari pendapatan tersebut, kemudian didistribusikan kepada para nasabah penyimpan dana (Muhammad, 2004:8).

Faktor internal bank juga dapat meliputi profit atau pendapatan laba bank syariah. Syamsuddin (2007:62) menyatakan bahwa

Net profit margin adalah merupakan rasio antara laba bersih (net profit) yaitu penjualan sesudah dikurangi dengan seluruh expense termasuk pajak dibandingkan dengan penjualan. Semakin tinggi NPM, semakin baik operasi suatu perusahaan.

Net profit margin menunjukan seberapa besar imbal hasil yang sanggup diberikan bank terhadap nasabah. 
Devita, et al/Jurnal Ekonomi Syariah Teori dan Terapan Vol. 3 No. 8 Agustus 2016: 600-614; ANALISIS KRITERIA PENETAPAN NILAI BAGI HASIL PENDANAAN DENGAN MENGGUNAKAN TEKNIK ANP (STUDI KASUS PADA BANK JATIM SYARIAH)

Profit bank syariah yang terlalu rendah akan menarik perhatian dewan direksi untuk melakukan kebijakan dalam penetapan bagi hasil. Direksi adalah organ perseroan yang berwenang dan bertanggung jawab penuh atas pengurus perseroan untuk kepentingan perseroan, sesuai dengan maksud dan tujuan perseroan serta mewakili perseroan baik di dalam maupun di luar pengadilan sesuai dengan ketentuan anggaran dasar (UU No 40 Tahun 2007 Tentang Perseroan Terbatas).

Dalam penetapan bagi hasil, sikap pemerintah dalam dalam membuat kebijakan juga perlu diperhatikan. Pendapatan bank syariah yang akan dialokasikan untuk dibagikan kepada nasabah akan dipengaruhi adanya kebijakan pemerintah terhadap pengusaha salah satunya perizinan usaha. Menurut Lembaga Administrasi Negara Republik Indonesia (1997:138) perizinan adalah salah satu bentuk pelaksanaan dari fungsi dan pengaturan yang bersifat pengendalian yang dimiliki oleh pemerintah terhadap kegiatan-kegiatan yang dilakukan oleh masyarakat.

Menurut UU No.28 Tahun 2007

Pasal 1 Tentang Ketentuan Umum dan Perpajakan, pajak merupakan suatu konstribusi wajib kepada negara yang terhutang oleh setiap orang maupun badan yang sifatnya memaksa namun tetap berdasarkan pada UndangUndang, dan tidak mendapat imbalan secara langsung serta digunakan untuk kebutuhan negara juga kemakmuran rakyatnya. Kebijakan pemerintah dalam penetapan pajak akan sangat mempengaruhi pergerakan pengusaha dan akan berdampak pada pendapatan yang akan diperoleh oleh bank syariah.

Penetapan bagi hasil juga harus memperhatikan kondisi ekonomi salah satunya yaitu kondisi pasar. Swastha (1998:27) menjelaskan bahwa penjual harus dapat meyakinkan pembeli agar berhasil mencapai sasaran penjualan yang diharapkan untuk maksud tersebut. Dari pernyataan tersebut dapat disimpulkan bahwa dalam menetapkan bagi hasil juga harus sesuai dengan kondisi pasar agar sesuai dengan sasaran.

Kondisi ekonomi lainnya yang juga harus diperhatikan yaitu harga barang pokok. Menurut Kartadinata (2000:1) harga pokok bagi suatu perusahaan perdagangan hanya mengandung satu unsur saja, yakni harga beli produk-produk yang diperdagangkan. Dalam konteks ini, apabila harga barang pokok tinggi maka pengusaha juga akan mengalami kesulitan dalam proses produksi dan akan berdampak pada pendapatan bank syariah.

Bagi hasil pendanaan merupakan suatu ketetapan yang penting bagi bank syariah. Kesalahan dalam penetapan bagi hasil akan berakibat pada hilangnya nasabah yang merupakan suatu hal yang krusial bagi bank syariah itu sendiri. Oleh karena itu dalam penetapannya dibutuhkan analisis terhadap kriteriakriteria terkait. Dengan kata lain penetapan bagi hasil merupakan 
Devita, et al/Jurnal Ekonomi Syariah Teori dan Terapan Vol. 3 No. 8 Agustus 2016: 600-614; ANALISIS KRITERIA PENETAPAN NILAI BAGI HASIL PENDANAAN DENGAN MENGGUNAKAN TEKNIK ANP (STUDI KASUS PADA BANK JATIM SYARIAH)

keputusan yang krusial bagi kesehatan keuangan bank syariah tersebut.

Salah satu metode yang relevan dipakai dalam mengetahui pertimbangan yaitu metode ANP (Analytic Network Process). ANP merupakan metode yang relevan dipakai sebab ANP mengasumsikan faktor atau kriteria yang berpengaruh memiliki interdependensi. Menurut Ikbar (2007) interdependensi merupakan saling ketergantungan yang mempertemukan kekurangan dari masing-masing kriteria melalui keunggulan komparatif. Metode ANP yaitu metode yang digunakan untuk menentukan keterkaitan atau interdependensi berdasarkan beberapa kriteria yang dipertimbangkan.

Peneliti memilih Bank Jatim Unit Usaha Syariah atau Bank Jatim Syariah (BJS) karena memiliki tingkat bagi hasil yang cukup bersaing dengan bank syariah lainnya. Selama tujuh tahun beroperasi BJS telah hadir dengan banyak melakukan pengembangan dan inovasi guna memberikan layanan financial yang terbaik sesuai kebutuhan nasabah melalui beragam produk dengan prinsip syariah. Pada Penelitian ini peneliti memilih Bank Jatim Syariah sebagai subjek penelitian karena Bank Jatim Syariah merupakan bank regional yang besar di Jawa Timur serta tidak dipengaruhi undang-undang dalam pengambilan keputusannya.

Berdasarkan latar belakang di atas, maka peneliti tertarik untuk melakukan penelitian dengan judul
"Analisis Penetapan Nilai Bagi Hasil Pendanaan Berdasarkan Tingkat Interdependensi Faktor Internal dan Eksternal dengan Menggunakan Teknik ANP (Studi Kasus Pada Bank Jatim Syariah)".

Berdasarkan latar belakang di atas dapat dirumuskan pokok permasalahan, apa yang menjadi kriteria utama dalam penetapan nilai bagi hasil pendanaan berdasarkan tingkat interdependensi faktor internal dan eksternal dengan menggunakan teknik ANP (Studi Kasus Pada Bank Jatim Syariah)?

Tujuan dari penelitian ini adalah untuk mengetahui apa yang menjadi kriteria utama dalam penetapan nilai bagi hasil pendanaan berdasarkan tingkat interdependensi faktor internal dan eksternal dengan menggunakan teknik ANP (Studi Kasus Pada Bank Jatim Syariah)

\section{LANDASAN TEORI}

Menurut Muhammad (2004:1) bank syariah adalah bank yang beroperasi dengan tidak mengandalkan pada bunga. Bank Islam atau biasa disebut dengan Bank Tanpa Bunga, adalah lembaga keuangan/perbankan yang operasional dan produknya dikembangkan berlandaskan pada AlQur'an dan Hadits Nabi SAW.

Dana adalah uang tunai yang dimiliki dan dikuasai oleh bank dalam bentuk tunai atau aktiva lain yang dapat segera diubah menjadi uang tunai. Uang tunai yang dimiliki atau dikuasai oleh bank tidak hanya berasal dari para pemilik bank itu sendiri, tetapi juga berasal dari 
Devita, et al/Jurnal Ekonomi Syariah Teori dan Terapan Vol. 3 No. 8 Agustus 2016: 600-614; ANALISIS KRITERIA PENETAPAN NILAI BAGI HASIL PENDANAAN DENGAN MENGGUNAKAN TEKNIK ANP (STUDI KASUS PADA BANK JATIM SYARIAH)

titipan atau penyertaan dana orang lain atau pihak lain yang sewaktu-waktu atau pada saat tertentu akan ditarik kembali. (Arifin, 2002: 160).

Menurut Karim (2007:97), dalam penghimpunan dana bank syariah memiliki produk berupa (1) giro, (2) tabungan dan (3) deposito. Menurut dewan syariah nasional giro dan tabungan yang boleh dilakukan oleh bank syariah adalah giro yang dilaksanakan dengan prinsip wadiah dan mudharabah. Sedangkan deposito yang dibolehkan adalah deposito dalam bentuk mudharabah. Berdasarkan kewenangan dari pemilik dana bentuk deposito dapat dibagi dua menjadi mudharabah muttaqah dan mudharabah muqayyadah.

Menurut Bank Indonesia produk yang tersedia di perbankan syariah hampir serupa dengan yang tersedia di bank konvensional, diantaranya titipan, tabungan, deposito, jasa, dan peminjaman. Beberapa jenis produk perbankan syariah saat ini diantaranya:

1. Giro

Giro adalah salah satu produk simpanan yang berupa titipan dana dari pihak ketiga yang dikelola oleh bank berdasarkan prinsip syariah, dimana untuk melakukan penarikan dana dapat dilakukan dengan menggunakan cek, bilyet giro, atau dengan pemindahbukuan. Ada dua jenis giro yang dibedakan berdasarkan akad yang digunakan yaitu giro wadiah dan giro mudharabah.

2. Tabungan

Tabungan adalah simpanan berdasarkan akad wadiah (titipan), bagi hasil (mudharabah) atau dengan akad lainnya yang tidak bertentangan dengan prinsip-prinsip Islam. Penarikan vang tersebut hanya dapat dilakukan menurut syatar-syarat dan ketentuan tertentu.

Dalam operasional bank syari'ah, menerapkan dua aqad dalam tabungan, yaitu wadi'ah dan mudharabah. Tabungan yang menerapkan wadi'ah, mengikuti prinsip-prinsip wadi'ah yad adhdhamanah, dimana tabungan ini tidak mendapatkan imbalan bagi hasil, karena sifatnya titipan dan dapat diambil dengan mengunakan buku tabungan atau melalui ATM.

3. Deposito

Deposito merupakan salah satu bentuk simpanan di bank yang dapat menjadi investasi kedepannya. Bank syariah memiliki salah satu produk deposito yang menggunakan akad mudharabah dan sesuai dengan syariah.

$$
\text { Muhammad }
$$
mendefinisikan sistem bagi hasil sebagai sistem pembagian hasil kerjasama baik berupa keuntungan (profit) maupun pendapatan (revenue) berdasarkan nisbah yang telah disepakati di awal akad dari kerjasama minimal antara dua pihak atau lebih, satu pihak berperan sebagai 
Devita, et al/Jurnal Ekonomi Syariah Teori dan Terapan Vol. 3 No. 8 Agustus 2016: 600-614; ANALISIS KRITERIA PENETAPAN NILAI BAGI HASIL PENDANAAN DENGAN MENGGUNAKAN TEKNIK ANP (STUDI KASUS PADA BANK JATIM SYARIAH)

penyandang dana dan pihak lainnya sebagai pekerja.

Muhammad (2012:99) menyatakan bahwa nisbah bagi hasil merupakan presentase keuntungan yang akan diperoleh shahibul mal dan mudharib yang ditentukan berdasarkan kesepakatan antara keduanya. Jika usaha tersebut merugi akibat resiko bisnis, bukan akibat kelalaian mudharib, maka pembagian kerugiannya berdasarkan porsi modal yang disetor oleh masingmasing pihak. Karena seluruh modal yang ditanam dalam usaha mudharib milik shahibul mal,maka kerugiannya dari usaha tersebut ditanggung sepenuhnya oleh shahibul mal. Oleh karena itu, nisbah bagi hasil disebut juga dengan nisbah keuntungan.

Larangan riba tercantum dalam Al-Qur'an dan As-Sunnah. Dalam AlQur'an Surat Al-Imron: 130

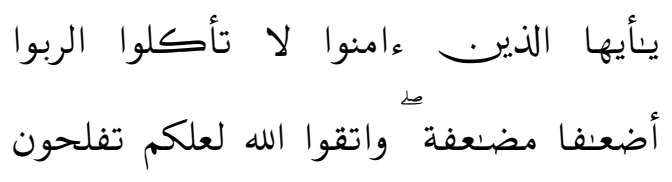

YÉ'ayyuhÉ'l-laĐÊna 'Éman $\ddot{E} \quad l E ́$ ta'kul̈̈'r-ribÉ aİ'ÉfammuİE'afatan wÉttaq ̈̈'l-Laha la'allakum tufliÍË́n.

Artinya: "Wahai orang-orang yang beriman! janganlah kamu memakan Riba dengan berlipat ganda dan bertakwalah kamu kepada Allah agar kamu beruntung."(Departemen Agama RI, 2007:66)

Menurut Bank Indonesia, produk pendanaan/simpanan bank syariah, misalnya Tabungan dan Deposito, penentuan nisbah bagi hasil dipengaruhi oleh beberapa faktor, yaitu: jenis produk simpanan, perkiraan pendapatan investasi dan biaya operasional bank. Hanya produk simpanan bank syariah dengan skema investasi (mudharabah) yang mendapatkan return bagi hasil. Sementara itu untuk produk simpanan bank syariah dengan skema titipan (wadiah), return yang diberikan berupa bonus. (www.bi.go.id)

Faktor internal merupakan faktorfaktor yang bersumber dari dalam bank yang mempengaruhi manajemen Bank antara lain berkaitan dengan pengambilan kebijakan dan strategi operasional bank antara lain:

Dana yang telah diperoleh bank syariah akan dialokasikan untuk memperoleh pendapatan. Dari pendapatan tersebut, kemudian didistribusikan kepada para nasabah penyimpan dana (Muhammad, 2004:8).

$$
\text { Sesuai dengan akad-akad }
$$
penyaluran pembiayaan di bank syariah, maka hasil penyaluran dana tersebut dapat memberikan pendapatan bagi bank syariah. Hal ini dapat dikatakan sebagai sumber-sumber pendapatan bank syariah. Dengan demikian, sumber pendapatan bank syariah dapat diperoleh dari (Muhammad, 2004): 
Devita, et al/Jurnal Ekonomi Syariah Teori dan Terapan Vol. 3 No. 8 Agustus 2016: 600-614; ANALISIS KRITERIA PENETAPAN NILAI BAGI HASIL PENDANAAN DENGAN MENGGUNAKAN TEKNIK ANP (STUDI KASUS PADA BANK JATIM SYARIAH)

1. Bagi hasil atas kontrak mudharabah dan kontrak musyarakah;

2. Keuntungan atas kontrak jual-beli (bai');

3. Hasil sewa atas kontrak ijarah (ijarah wa iqtina/ijarah muntahiyyah bit tamlik);

4. Fee dan biaya administrasi atas jasajasa lainnya.

Direksi adalah organ perseroan yang berwenang dan bertanggung jawab penuh atas pengurus perseroan untuk kepentingan perseroan, sesuai dengan maksud dan tujuan perseroan serta mewakili perseroan baik di dalam maupun di luar pengadilan sesuai dengan ketentuan anggaran dasar (UU No 40 Tahun 2007 Tentang Perseroan Terbatas).

Syamsuddin (2007:62) menyatakan bahwa net profit margin adalah merupakan rasio antara laba bersih (net profit) yaitu penjualan sesudah dikurangi dengan seluruh expense termasuk pajak dibandingkan dengan penjualan. Semakin tinggi NPM, semakin baik operasi suatu perusahaan.

Sikap pemerintah merupakan kebijakan pemerintah yang mempengaruhi manajemen bank antara lain berkaitan dengan pengambilan kebijakan dan strategi operasional bank antara lain:

Menurut Lembaga Administrasi Negara Republik Indonesia (1997:138) perizinan adalah salah satu bentuk pelaksanaan dari fungsi dan pengaturan yang bersifat pengendalian yang dimiliki oleh pemerintah terhadap kegiatan- kegiatan yang dilakukan oleh masyarakat. Perizinan dapat berbentuk pendaftaran, rekomendasi, sertifikasi dan izin untuk melakukan usaha yang biasanya harus dimiliki atau diperoleh suatu organisasi perusahaan atau seseorang sebelum yang bersangkutan dapat melakukan suatu kegiatan atau tindakan.

Menyadari bahwa sektor usaha kecil dan menengah ini sebagai penunjang ekonomi Indonesia namun umumnya memiliki keterbatasan sumber daya, maka Pemerintah mengeluarkan salah satu kebijakan untuk memberikan kemudahan bagi usaha kecil dan menengah (UKM) ini dalam memenuhi kewajiban perpajakannya. Kebijakan ini diatur dalam Peraturan Pemerintah Nomor 46 Tahun 2013 tentang Pajak Penghasilan atas Penghasilan dari Usaha yang diterima atau diperoleh Wajib Pajak yang Memiliki Peredaran Bruto Tertentu.

Kebijakan ini mengatur bagi Wajib Pajak (baik yang berupa perseorangan maupun yang berbentuk badan usaha) dengan peredaran bruto dalam 1 (satu) tahun pajaknya tidak melebihi Rp 4,8 miliar (diistilahkan sebagai Wajib Pajak yang memiliki peredaran bruto tertentu) dikenai Pajak Penghasilan sebesar $1 \%$ dari peredaran bruto (omzet) dan bersifat final. Kebijakan ini dibuat dengan tujuan untuk menyederhanakan dan memudahkan dalam melakukan pemenuhan kewajiban PPh bagi Wajib Pajak Usaha Kecil dan Menengah.

Kondisi perekonomian yang mempengaruhi manajemen bank antara 
Devita, et al/Jurnal Ekonomi Syariah Teori dan Terapan Vol. 3 No. 8 Agustus 2016: 600-614; ANALISIS KRITERIA PENETAPAN NILAI BAGI HASIL PENDANAAN DENGAN MENGGUNAKAN TEKNIK ANP (STUDI KASUS PADA BANK JATIM SYARIAH)

lain berkaitan dengan pengambilan kebijakan dan strategi operasional bank antara lain:

Menurut Mulyadi (2010:65) dalam perusahaan berproduksi umum, informasi harga pokok produksi yang dihitung untuk jangka waktu tertentu bermanfaat bagi manajemen untuk :

1. Menentukan harga jual produk.

2. Memantau realisasi biaya produksi.

3. Menghitung laba atau rugi periodik.

4. Menentukan harga pokok persediaan produk jadi dan produk dalam proses yang disajikan dalam neraca.

Swastha (1998:27) menyatakan bahwa hal yang harus diperhatikan pada kondisi pasar antara lain :

1. Jenis pasarnya, apakah pasar konsumen, pasar industri, pasar pemerintahan atau pasar Internasional

2. Kelompok pembeli dan segmen pasarnya

3. Daya beli

4. Frekuensi pembeliannya

5. Keinginan dan kebutuhan Metode Analytic Network Process (ANP) merupakan suatu metode yang mampu memperbaiki kelemahan dari metode Analytical Hierarchy Process (AHP) berupa kemampuan mengakomodasi keterkaitan antar kriteria atau alternative (Saaty, 2004).

Analytic Network Process (ANP) merupakan alat analisis yang mampu merepresentasikan tingkat kepentingan berbagai pihak dengan mempertimbangkan hubungan ketergantungan baik antar kriteria maupun sub kriteria. ANP adalah teori umum pengukuran relatif yang digunakan untuk menurunkan rasio prioritas komposit dari skala rasio individu yang mencerminkan pengukuran relatif dari pengaruh elemen-elemen yang saling berinteraksi berkenan dengan kriteria control (Saaty, 2004).

\section{METODE PENELITIAN}

\section{Pendekatan Penelitian}

Penelitian ini menggunakan pendekatan kualitatif deskriptif dengan metode studi kasus. Menurut Sugiyono (2009:14) metode penelitian kualitatif adalah metode penelitian yang berlandaskan pada filsafat postpositivisme, digunakan untuk meneliti pada kondisi obyek yang alamiah, (sebagai lawannya eksperimen) dimana peneliti adalah sebagai instrument kunci, pengambil sampel sumber data dilakukan secara purposive dan snowball, teknik pengumpulan dengan triangulasi (gabungan), analisis data bersifat induktif/kualitatif, dan hasil penelitian kualitatif lebih menekankan makna dari pada generalisasi.

Menurut Yin (2006:18) metode studi kasus adalah suatu penelitian empiris yang menyelidiki fenomena dengan konteks kehidupan nyata, bilamana batas-batas antara fenomena dengan konteks tidak tampak dengan tegas dan multisumber digunakan.

\section{Jenis dan Sumber Data}

1. Data primer

Data primer diperoleh dari wawancara dan kuisioner kepada 3 
Devita, et al/Jurnal Ekonomi Syariah Teori dan Terapan Vol. 3 No. 8 Agustus 2016: 600-614; ANALISIS KRITERIA PENETAPAN NILAI BAGI HASIL PENDANAAN DENGAN MENGGUNAKAN TEKNIK ANP (STUDI KASUS PADA BANK JATIM SYARIAH)

informan pemegang kebijakan yang berwenang dalam pengambilan keputusan yang berada di Bank Jatim Syariah yaitu pemimpin divisi bisnis syariah, pemimpin sub divisi dana jasa dan penyelia dana jasa.

2. Data sekunder

Data sekunder diperoleh dari dokumen-dokumen yang diperoleh dari Bank Jatim Syariah serta dari studi kepustakaan yang memuat literaturliteratur tentang ekonomi Islam, jurnal, buku, artikel, situs-situs web, dan hasil karya ilmiah sebelumnya.

\section{Prosedur Pengumpulan Data}

1. Wawancara

Peneliti menggali segala informasi mengenai profil, latar belakang, serta proses pengambilan keputusan yang ada di Bank Jatim Syariah melalaui wawancara dengan pihak-pihak yang terkait dalam penelitian ini.

2. Kuesioner

Kuesioner dalam penelitian ini diberikan kepada informan yang berperan dalam penetapan nilai bagi hasil pendanaan. Kuesioner ini diberikan bertujuan untuk mendapatkan data penelitian mengenai kriteria yang paling berpengaruh dalam menetapkan nilai bagi hasil pendanaan. Kuesioner dalam bentuk pembobotan atas kriteria dan sub kriteria yang dipertimbangkan dalam penetapan nilai bagi hasil pendanaan yang dilakukan oleh pengambil keputusan di Bank Jatim Syariah.

3. Dokumentasi
Pengumpulan data untuk dokumentasi ini meliputi, data-data profil Bank Jatim Syariah, data bagi hasil pada berbagai produk pendanaan Bank Jatim Syariah.

\section{Validasi Data}

Dalam penelitian ini peneliti menggunakan triangulasi sumber yaitu dengan mewawancarai informan dari Bank Jatim Syariah untuk mendapatkan data yang valid. Kemudian menggunakan triangulasi teknik yaitu dengan menggunakan teknik wawancara pada awalnya, lalu memberikan kuisioner untuk mendapatkan data yang sejenis, dilanjutkan dengan dokumentasi sehingga data yang diperoleh dapat bersifat homogen dan valid.

\section{Teknik Analisis}

Peneliti menggunakan teknik ANP dengan pengolahan data untuk pembobotan ANP menggunakan data yang diperoleh dari hasil kuisioner dan dibantu dengan software SuperDecicions.

Menurut Yuksel dan Dagdeviren (2007) berikut ini adalah tahapantahapan yang harus dilakukan untuk mengerjakan ANP:

1. Mengkonstruksikan model

2. Membuat matriks perbandingan berpasangan dan vektor prioritas

3. Menghitung Rasio Konsistensi

4. Membentuk Supermatriks

5. Pemilihan alternatif terbaik

IV. HASIL DAN PEMBAHASAN

Kriteria dan sub kriteria yang dihasilkan dari wawancara adalah sebagai berikut: 
Devita, et al/Jurnal Ekonomi Syariah Teori dan Terapan Vol. 3 No. 8 Agustus 2016: 600-614; ANALISIS KRITERIA PENETAPAN NILAI BAGI HASIL PENDANAAN DENGAN MENGGUNAKAN TEKNIK ANP (STUDI KASUS PADA BANK JATIM SYARIAH)

a. Kriteria faktor internal, sub kriteria faktor internal yang digunakan dalam penelitian ini yaitu:

1. Pendapatan

2. Sikap dewan direksi

3. Net profit margin

b. Kriteria sikap pemerintah, sub kriteria sikap pemerintah yang digunakan dalam penelitian ini yaitu:

1. Penetapan pajak

2. Perizinan usaha

c. Kriteria kondisi perekonomian, sub kriteria kondisi perekonomian yang digunakan dalam penelitian ini yaitu:

1. Harga barang pokok

2. Pressing pasar

Analisis penentuan prioritas antar sub kriteria lintas cluster dilakukan dengan menginput output pembobotan masingmasing sub kriteria lintas cluster pada masing-masing informan untuk membentuk supermatriks dengan software super decisions. Supermatriks yang dihasilkan berupa unweighted supermatrix, weighted supermatrix, dan Limit matrix. Limit matrix berisi bobot prioritas global dalam weighted supermatrix yang telah konvergen dan stabil.

Setelah memperoleh nilai setiap sub kriteria pada limit matriks, langkah selanjutnya adalah melakukan perhitungan rata-rata geometri. Nilai ratarata geometri tertinggi akan menunjukkan sub kriteria yang menjadi prioritas dalam penetapan nilai bagi hasil di Bank Jatim Syariah.
Rata-rata geometrik tiap sub kriteria dari ketiga informan. Hasil ANP yang ditunjukkan melalui rata-rata geometrik menunjukkan bahwa urutan prioritas dalam penetapan nilai bagi hasil antara lain pendapatan bank sebesar 0,17416, net profit margin sebesar 0,156803 , sikap dewan direksi sebesar 0,1439, harga barang pokok sebesar 0,133746 , pajak bagi pengusaha sebesar 0,131959, pressing pasar 0,131374, dan perizinan usaha sebesar 0,127976. Dapat disimpulkan bahwa dari cluster faktor internal yang menjadi pertimbangan paling penting yaitu pendapatan bank. Dari cluster sikap pemerintah yang menjadi pertimbangan paling penting yaitu pajak bagi pengusaha. Kemudian dari cluster kondisi perekonomian yang menjadi pertimbangan paling penting yaitu harga barang pokok.

Tingkat presentase prioritas pertimbangan penetapan nilai bagi hasil pendanaan dapat dilihat pada gambar berikut:

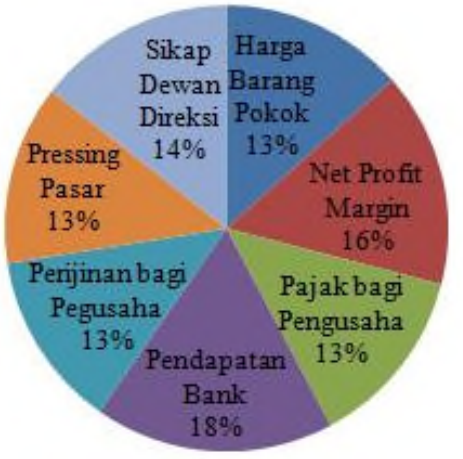

Gambar 1.

Presentase Prioritas Penetapan Nilai Bagi

Hasil Pendanaan Bank Jatim Syariah

Pendapatan bank menjadi sub kriteria yang paling dipertimbangkan 
Devita, et al/Jurnal Ekonomi Syariah Teori dan Terapan Vol. 3 No. 8 Agustus 2016: 600-614; ANALISIS KRITERIA PENETAPAN NILAI BAGI HASIL PENDANAAN DENGAN MENGGUNAKAN TEKNIK ANP (STUDI KASUS PADA BANK JATIM SYARIAH)

sebesar $18 \%$ dibanding lainnya dalam penetapan nilai bagi hasil pendanaan di Bank Jatim Syariah karena pendapatan bank merupakan aktiva produktif yang diperoleh dari aktivitas pembiayaan maupun dari investasi sehingga paling mudah untuk dilakukan perhitungan bagi hasil. Sedangkan perizinan usaha kurang dipertimbangkan dibanding sub kriteria yang lain karena tidak berdampak secara langsung bagi bank syariah melainkan berdampak bagi pengusaha yang ingin mendirikan usaha sehingga sulit untuk diukur.

Pendapatan merupakan jumlah dana yang diperoleh bank syariah dari bagi hasil atas kontrak mudharabah dan kontrak musyarakah, keuntungan atas kontrak jual-beli (bai'), hasil sewa atas kontrak ijarah (ijarah wa iqtina/ijarah muntahiyyah bit tamlik), serta Fee dan biaya administrasi atas jasa-jasa lainnya. Pendapatan bank menjadi kriteria yang menjadi pertimbangan utama penetapan bagi hasil pendanaan dengan pertimbangan bahwa pendapatan merupakan dana yang telah diperoleh bank syariah dan dari pendapatan tersebut kemudian didistribusikan kepada para nasabah penyimpan dana. Islam mengajarkan keadilan terhadap persaudaraan manusia, maka ketidakadilan pendistribusian pendapatan akan bertentangan dengan Islam. Ketidakadilan akan menghancurkan rasa persaudaraan yang ingin ditumbuhkan oleh Islam. Berdasarkan Al Qur'an Surat Al Baqarah ayat 29 semua sumber daya adalah anugerah dari Allah bagi umat manusia.

$$
\begin{aligned}
& \text { هو الذى خلقـ لكم ما في الأرض جميعا ثم } \\
& \text { استوى إلى السماء فسونهن سبع سمو'ت وهو } \\
& \text { بكل شىء عليم }
\end{aligned}
$$

Huwal-laĐÊna kholaqo lakummÉ filarìi jamê'an śumma-stawÉ ilÉ-samÉi fasawwÉhunna sab'a samawÉti wa huwa bikulli syaiin 'alÊm.

Artinya: "Dia-lah Allah, yang menjadikan segala yang ada di bumi untuk kamu"

Dalam ayat tersebut dijelaskan bahwa segala yang ada di bumi adalah untuk manusia sehingga pendistribusian pendapatan berupa bagi hasil kepada nasabah penyimpan dana di bank syariah harus dilakukan secara adil dan sesuai dengan porsi dana masing-masing nasabah.

Tidak ada alasan kekayaan sumber daya tersebut tetap terkonsentrasi pada beberapa pihak saja. Oleh karena itu, Islam sangat menekankan keadilan distributif dan menerapkannya dalam sistem ekonomi program untuk redistribusi pendapatan dan kekayaan sehingga setiap individu mendapatkan jaminan standar kehidupan yang manusiawi dan terhormat. Hal ini pun selaras dengan perhatian Islam terhadap tugas seorang manusia dalam ajaran Islam yaitu sebagai khalifah atau wakil Allah dimuka bumi seperti dalam Surat Al Baqarah ayat 30 
Devita, et al/Jurnal Ekonomi Syariah Teori dan Terapan Vol. 3 No. 8 Agustus 2016: 600-614; ANALISIS KRITERIA PENETAPAN NILAI BAGI HASIL PENDANAAN DENGAN MENGGUNAKAN TEKNIK ANP (STUDI KASUS PADA BANK JATIM SYARIAH)

$$
\begin{aligned}
& \text { وإذ قال ربكــ للمليكة إنى جاعل في الأرض } \\
& \text { خليفة قالوا أتجعل فيها من يفسد فيها ويسفك } \\
& \text { الدماء وخن نسبح نحمدك ونقدس لك قال إنى } \\
& \text { أعلم ما لا تعلمون }
\end{aligned}
$$

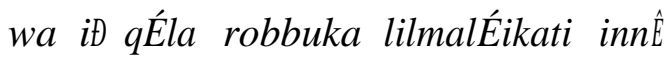
jÉilun fil-arİi kholifatan qol̈̈ ataj'alu ḟ̂hÉ wa yasfikud-dimÉa wa naÍnu nusabbiÍ u biÍamdika wa nuqoddisu laka qÉla innỂ a'lamu mÉlÉ ta'lamËna

Artinya: "Sesungguhnya Aku hendak menjadikan seorang khalifah di muka bumi"

Bank syariah dalam menjalankan kewajibannya salah satunya membuat laporan keuangan harus jujur dan bertanggung jawab. Pendapatan yang diperoleh bank syariah harus dilaporkan secara jelas dan transparan. Di dalam pendapatan yang diperoleh bank syariah ada hak yang harus dibagikan kepada nasabah berupa bagi hasil. Islam sangat melarang manusia untuk memakan hak orang lain. Seperti yang dijelaskan dalam Surat Al-Baqarah ayat 188.

$$
\begin{aligned}
& \text { ولا تأكلوا أمو'لكم بينكم بالبنطل وتدلوا بها إلى } \\
& \text { الححكام لتأكلوا فريقا من أمو'ل الناس بالإثم } \\
& \text { وأنتم تعلمون }
\end{aligned}
$$

walÉ ta'kul̈̈ 'amwÉ lakum baynakum bil bÉtili watudl̈̈ bihÉ ilÉ'l-hukkÉmi lita'kul̈̈ faryqan min 'amwÉli'-nÉsi bi'l-'ismi wa'antum ta'lamËna.

Artinya: "Dan janganlah sebahagian kamu memakan harta sebahagian yang lain di antara kamu dengan jalan yang bathil dan (janganlah) kamu membawa (urusan) harta itu kepada hakim, supaya kamu dapat memakan sebahagian daripada harta benda orang lain itu dengan (jalan berbuat) dosa, Padahal kamu mengetahui."

Dalam ayat tersebut Allah sangat melarang manusia yang memakan harta sesama manusia dengan cara yang bathil. Penulisan laporan keuangan salah satunya yaitu penulisan pendapatan bank syariah harus dilakukan secara jujur dan transparan karena memanipulasi atau mengubah besaran penulisan pendapatan pada laporan keuangan bank syariah akan mempengaruhi bagi hasil yang nantinya akan diterima oleh nasabah.

\section{v. SIMPULAN}

Berdasarkan hasil analisis dari hasil pengolahan data dengan menggunakan teknik Analytic Network Process (ANP), maka dapat ditarik kesimpulan hasil dari penelitian ini adalah kriteria faktor internal dengan sub kriteria pendapatan bank sebesar 0,17416 menjadi kriteria utama dalam penetapan nilai bagi hasil pendanaan di Bank Jatim Syariah. Sub kriteria sikap pemerintah yang paling utama yaitu pajak bagi pengusaha sebesar 0,131959. Sub kriteria kondisi perekonomian yang paling utama yaitu harga barang pokok sebesar 0,133746.

\section{DAFTAR PUSTAKA}

Arifin, Ali. 2002. Membaca Saham. Jakarta: PT Raja Gramedia.

Bustami Bastian., Nurlela. 2010. Akuntansi Biaya. Yogyakarta: Graha llmu. 
Devita, et al/Jurnal Ekonomi Syariah Teori dan Terapan Vol. 3 No. 8 Agustus 2016: 600-614; ANALISIS KRITERIA PENETAPAN NILAI BAGI HASIL PENDANAAN DENGAN MENGGUNAKAN TEKNIK ANP (STUDI KASUS PADA BANK JATIM SYARIAH)

Chaudhry, Muhammad Sharif. 2012. Sistem

Ekonomi Islam Prinsip Dasar. Jakarta: Kencana.

Departemen Agama RI. 2007. Al-Qur'an dan Terjemahnya. Bandung: Syaamil Cipta Media.

Ikbar, Yanuar. 2007. Ekonomi Politik Internasional 2: Implementasi Konsep dan Teori. Bandung: PT Refika Aditama.

Karim, Adiwarman. 2007. Bank Islam Analisis, Fiqih, dan Keuangan. Edisi 3. Jakarta: PT Raja Grafindo Persada.

Kartadinata, Abas. 2000. Akuntansi dan Analisis Biaya. Jakarta: PT. Rineka Cipta.

Lembaga Administrasi Negara Republik Indonesia. 1997. Sistem Administrasi Negara Republik Indonesia, Jilid II/ Edisi Ketiga. Jakarta: Gunung Agung.

Muhammad. 2004. Manajemen Dana

Bank Syariah. Yogyakarta: Ekonisia.

Muhammad. 2002. Manajemen

Bank

Syari'ah. Jogjakarta: (UPP) AMP YKPN

Muhammad. 2012. Teknik

Perhitungan

Bagi Hasil dan Pricing di Bank Syariah.

Yogyakarta: UII Press.

Mulyadi. 2010. Sistem Akuntansi. Jakarta: Salemba Empat.

Republik Indonesia. 2008. Undang-Undang No 10 Tahun 1998 tentang perbankan syariah. (online), (http://www.bi.go.id, diakses tanggal 18 September 2015)

Republik Indonesia. 2008. Undang-Undang No 40 Tahun 2007 Tentang Perseroan Terbatas. (online),

(http://www.legalitas.org, diakses tanggal 15 Januari 2016)
Republik Indonesia. 2008. Undang-Undang UU No.28 Tahun 2007 Tentang Ketentuan Umum dan Perpajakan. (online), (http://www.legalitas.org, diakses tanggal 15 Januari 2016)

Republik Indonesia. 2008. Peraturan Pemerintah Nomor 46 Tahun 2013 tentang Pajak Penghasilan atas Penghasilan dari Usaha yang diterima atau diperoleh Wajib Pajak yang Memiliki Peredaran Bruto Tertentu. (online), (http://www.legalitas.org, diakses tanggal 15 Januari 2016)

Ikatan Akuntan Indonesia. 2010. PSAK No.

23. 2010. Paragraf 06. Jakarta: Salemba Empat.

Saaty, Thomas. 2004. Fundamentals Of The Analytic Network Process- Dependence And Feedback In Decicion-Making With A Single Network. Vol.13 no.2 : 129-157.

Sugiyono. 2009. Memahami Penelitian Kualitatif. Bandung: PT Remaja Rosidakarya.

Swastha, Basu. 1998. Manajemen Penjualan, Edisi 3. Yoyakarta: BPFE Universitas Gadjah Mada.

Syamsuddin, Lukman. 2007. Manajemen Keuangan Perusahaan: Konsep Aplikasi dalam Perencanaan, Pengawasan, dan Pengambilan Keputusan. Jakarta: Raja Grafindo

Tarsidin. 2010. Bagi Hasil: Konsep dan Analisis. Jakarta: FE UI.

Yin, Robert K. 2006. Studi Kasus: Desain dan Metode. Jakarta : PT Raja Grafindo Persada. 
Devita, et al/Jurnal Ekonomi Syariah Teori dan Terapan Vol. 3 No. 8 Agustus 2016: 600-614; ANALISIS KRITERIA PENETAPAN NILAI BAGI HASIL PENDANAAN DENGAN MENGGUNAKAN TEKNIK ANP (STUDI KASUS PADA BANK JATIM SYARIAH)

Yuksel, I \& Dagdeviren, M. 2007. Using the Analytic network process (ANP) in a SWOT Analysis - A Case Study for Textile Firm. An International Journal of Information Sciences: Elsevier Inc., p.4.

http://www.bankjatim.id Diakses 14 Desember 2015) http://www.bi.go.id/id/perbankan/edukas i/Pages/Menghitung_Bagi_Hasil_iB.aspx( Diakses 23 Oktober 2015) 